ARTICLE

\title{
A natural riboswitch scaffold with self-methylation activity
}

\author{
Laurin Flemmich', Sarah Heel ${ }^{1}$, Sarah Moreno', Kathrin Breuker $\mathbb{D}^{1}{ }^{1}$ \& Ronald Micura ${ }^{1 凶}$
}

Methylation is a prevalent post-transcriptional modification encountered in coding and noncoding RNA. For RNA methylation, cells use methyltransferases and small organic substances as methyl-group donors, such as S-adenosylmethionine (SAM). SAM and other nucleotidederived cofactors are viewed as evolutionary leftovers from an RNA world, in which riboswitches have regulated, and ribozymes have catalyzed essential metabolic reactions. Here, we disclose the thus far unrecognized direct link between a present-day riboswitch and its inherent reactivity for site-specific methylation. The key is $0^{6}$-methyl pre-queuosine $\left(m^{6}\right.$ preQ $\left._{1}\right)$, a potentially prebiotic nucleobase which is recognized by the native aptamer of a pre $Q_{1}$ class I riboswitch. Upon binding, the transfer of the ligand's methyl group to a specific cytidine occurs, installing 3-methylcytidine $\left(\mathrm{m}^{3} \mathrm{C}\right)$ in the RNA pocket under release of prequeuosine $\left(\right.$ preQ $\left._{1}\right)$. Our finding suggests that nucleic acid-mediated methylation is an ancient mechanism that has offered an early path for RNA epigenetics prior to the evolution of protein methyltransferases. Furthermore, our findings may pave the way for the development of riboswitch-descending methylation tools based on rational design as a powerful alternative to in vitro selection approaches.

\footnotetext{
${ }^{1}$ University of Innsbruck, Institute of Organic Chemistry and Center for Molecular Biosciences (CMBI), Innrain 80-82, Innsbruck 6020, Austria.

凶email: ronald.micura@uibk.ac.at
} 
$\mathrm{n}$ recent years, numerous discoveries of metabolite-sensing riboswitches hint at RNA World ribozymes that could have promoted chemical transformations ${ }^{1-3}$. One hypothesis suggests that present-day riboswitches for common enzyme cofactors may have evolved from ancient ribozymes that depended on these cofactors ${ }^{4-7}$. What has stood the test of time are RNA sensors of cofactors for the regulation of gene expression ${ }^{8}$ while the reactivity part has been taken over by more efficient proteinbased modification machineries ${ }^{9-12}$. Riboswitches typically employ a highly conserved aptamer domain to sense the small molecule ligand with high specificity and selectivity, and an adjoining expression platform to regulate the expression of genes associated with ligand biosynthesis and transport ${ }^{8,13,14}$. Thereby, the partially overlapping RNA sequences of the two domains assist in converting the ligand-binding event into a change in gene expression by employing ligand-mediated RNA folding changes. It seems reasonable to assume that ligandinduced structural adaptions may also be exploited to trigger a chemical reaction. A single example exists for a known naturally occurring RNA, namely the glms riboswitch-ribozyme which binds glucosamine-6-phosphate whose protonated amino group then directly participates in reaction catalysis of RNA backbone cleavage ${ }^{15}$. Moreover, support for an advanced reactivity scope of cofactor-RNA systems has been provided by ribozyme engineering. The first methyltransferase ribozyme that catalyzes the site-specific installation of 1-methyladenosine in a substrate RNA, using a small-molecule cofactor has been created by in vitro evolution very recently ${ }^{16}$.

Numerous natural riboswitches are known to selectively sense nucleotide-derived metabolites connected to methyl-group transfer or one-carbon metabolism, comprising SAM, methylene tetrahydrofolate (THF) and adenosylcobalamin (vitamin B12) ${ }^{17}$. The aptamers of these riboswitches bind their dedicated ligands in the nano- to micromolar range. For all of them, different subclasses are found, meaning that the ligand is recognized by distinct RNA architectures with both specific binding pockets as well as overall folds ${ }^{18}$. For SAM-binding riboswitches, a total of six subclasses is known to date; they accommodate the ligand with its reactive methyl group in conformations that strictly avoid self-methylation ${ }^{19,20}$.

Therefore, it has remained an open question whether riboswitches can catalyze site-specific methylation reactions to produce defined methylated RNA products9,11. Besides the abovementioned ubiquitous enzyme cofactors, other small organic compounds could serve for RNA-catalyzed RNA methylation in modern riboswitches, as implicated by the recently in vitro selected RNA methyltransferase that utilizes $O^{6}$-methyl guanine ${ }^{16}$. An obvious link between guanine riboswitches and the nearcognate ligand $O^{6}$-methyl guanine was tested even prior to the in vitro selected methyltransferase, however, methylation was not observed $^{21}$. Nevertheless, we speculated that other riboswitches sensing guanine-type ligands may possess the inherent reactivity for methyl group transfer that we were searching for. Here, we report on the identification of a riboswitch motif that uses $O^{6}$ methyl pre-queuosine $\left(\mathrm{m}^{6} \mathrm{preQ}_{1}\right)$ as a small-molecule methylgroup donor, catalyzing site-specific methylation of a cytosine at the N3-atom, resulting in RNA sequence-specific installation of 3methylcytidine $\left(\mathrm{m}^{3} \mathrm{C}\right)$ (Fig. 1).

\section{Results}

Reactivity predictions for the $\mathrm{preQ}_{1}$ riboswitch and ligand requirements. We started our ambitious scheme to uncover RNA methylation activity with the analysis of ligand binding sites of various riboswitches and soon focused on preQ $_{1}$ class I riboswitches (Fig. 2a) for which high-resolution crystal structures of

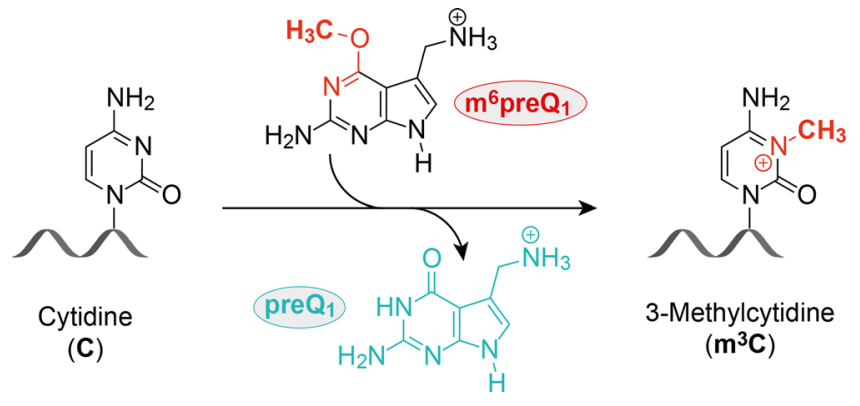

Fig. 1 RNA methyltransferase activity. RNA sequence-specific installation of N3-methyl cytidine $\left(\mathrm{m}^{3} \mathrm{C}\right)$ using the small molecule $\mathrm{m}^{6} \mathrm{preQ}_{1}$ as cofactor has been discovered and is described in this study. The direct link between a present-day riboswitch scaffold and RNA-catalyzed methylation is reported.

both ligand-free and ligand-bound states were available (Fig. 2b, c) $22-24$. This choice was also guided by our hypothesis that the methylated version of the cognate ligand $\mathrm{preQ}_{1}$, namely $\mathrm{m}^{6} \mathrm{preQ}_{1}$, might be an excellent candidate for methyl group donation since $\mathrm{m}^{6} \mathrm{preQ}_{1}$ should retain the majority of interactions with the RNA as encountered in the genuine ligand-riboswitch system. Moreover, the principal reactivity of $\mathrm{m}^{6} \mathrm{preQ}_{1}$ is expected to be comparable to $\mathrm{m}^{6} \mathrm{G}$ that serves as cofactor in the recently in vitro selected RNA methyltransferase ${ }^{16}$.

Figure $2 \mathrm{a}$ shows the sequence and secondary structure of the $33 \mathrm{nt}$ long aptamer of the Thermoanaerobacter tengcongensis $(\mathrm{Tt})$ preQ $_{1}$ riboswitch which adopts an H-type pseudoknot structure exhibiting low nanomolar affinity for preQ $_{1}$ (Fig. 2b). The ligand is recognized by forming a Watson-Crick base pair with C15 (Fig. 2d,e) while the ligand's N3 hydrogen acceptor and the C2$\mathrm{NH}_{2}$ group are recognized in bidentate fashion via the WatsonCrick face of A29, complemented by a single H-bond between $\mathrm{N} 9-\mathrm{H}$ and the carbonyl oxygen of U6. Furthermore, a critical interaction responsible for the high affinity of $\mathrm{preQ}_{1}$ is attributed to the 7-aminomethyl group and the carbonyl oxygen of G5. The tight binding pocket is further defined by preQ $Q_{1}$ stacking between the G5-C16 base pair and the nucleobase of G11 whose ribose $2^{\prime}$ $\mathrm{OH}$ is directed toward the $\mathrm{preQ}_{1} \mathrm{O} 6$ atom and the 7aminomethyl group (Fig. 2e). Importantly, the crystal structure of the ligand-free Tt RNA (Fig. 2c) points at the high flexibility and structural dynamics of parts of the binding pocket: C15 is now directed outwards while the nucleobase of its next neighbor (A14) slides into the stacked position filling the space of the former C15-preQ ${ }_{1}$ base pair.

Because of the above-highlighted characteristics in structure and structural dynamics of the $\mathrm{preQ}_{1}$ class I binding site we anticipated a high probability that the ligand congener $\mathrm{m}^{6} \mathrm{preQ}_{1}$ transfers its methyl group to the RNA: First of all, recognition of $\mathrm{m}^{6} \mathrm{preQ}_{1}$ by wild-type $\mathrm{C} 15$ should be easily possible if the tautomeric equilibrium is shifted towards the imino tautomer ${ }^{i m} \mathrm{C} 15$ (Fig. 2f). Second, the wild-type RNA pocket provides sufficient space to accommodate the methyl group (Fig. 2b,d). Third, there are three potential nucleophilic groups for methylation available in the vicinity of the methyl group if $\mathrm{m}^{6} \mathrm{preQ}_{1}$ becomes recognized by the pocket: these are the $2^{\prime}-\mathrm{OH}$ of $\mathrm{G} 11$, the $\mathrm{C} 4-\mathrm{NH}_{2}$ of $\mathrm{C} 15$, and the $\mathrm{N} 3$ of $\mathrm{C} 15$ (Fig. 2 d,e).

Identification of methylated RNA product and reaction conditions. A methylation product of the pre $Q_{1}$ riboswitch would be difficult to distinguish from the unmodified RNA by gel shift or HPLC assays because its expected retention time will hardly differ. Therefore, we set out for an advanced mass spectrometric technology, Fourier-transform ion cyclotron resonance (FT-ICR) 
a

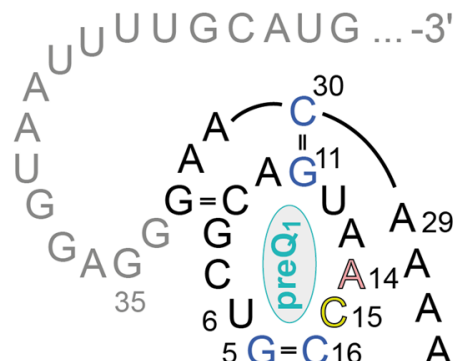

b

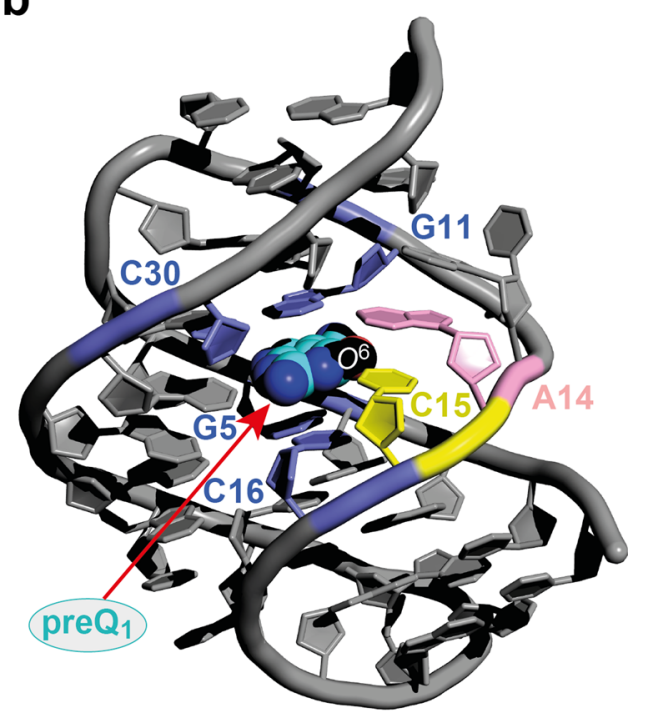

d

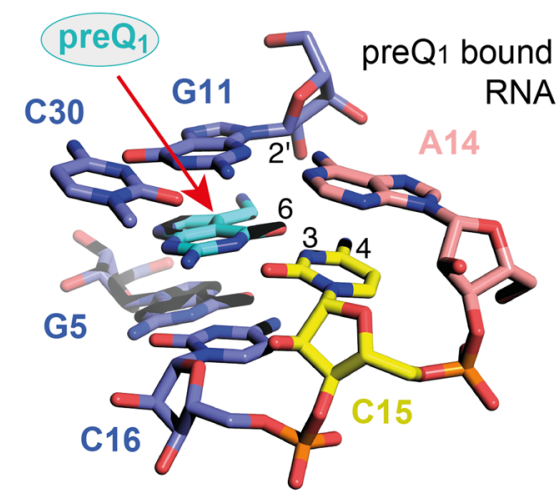

f<smiles></smiles>

m6reQ1

Fig. 2 Analysis of preQ $_{\mathbf{1}}-\mathbf{I}$ riboswitch structures in the light of reactivity prediction. a Sequence and secondary structure of the $T t$ pre $Q_{1}-1$ riboswitch

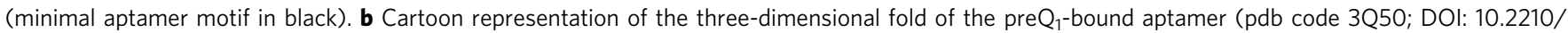
pdb3q50/pdb). c Stick representation of the ligand-free pocket revealing that A14 slides into the pocket and fills the space of preQ $\mathrm{Q}_{1}$ while $\mathrm{C} 15$ flips out and

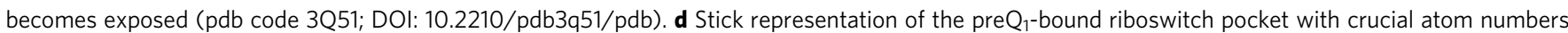
annotated in black. e Chemical structures illustrating the hydrogen bond network of preQ $\mathrm{Q}_{1}$ in the riboswitch pocket and the 2'-OH group of $\mathrm{G} 11$ that comes close the Hoogsteen face of $\mathrm{preQ}_{1}$. $\mathbf{f}$ Structure of a putative base pair between $\mathrm{C} 15$ (imino tautomer) and $\mathrm{m}^{6} \mathrm{preQ}_{1}$ in the preQ $\mathrm{Q}_{1}-\mathrm{I}$ riboswitch pocket.

mass spectrometry (MS), which can determine the mass-tocharge ratio $(\mathrm{m} / \mathrm{z})$ of ions with very high precision by measuring the frequency of their cyclotron motion in a static magnetic field ${ }^{25,26}$. A major strength of such a set-up is that an RNA can be directly sequenced along with the identification of modifications and their localization (top-down RNA characterization) as we have demonstrated earlier ${ }^{27}$.

We prepared the $33 \mathrm{nt}$ long $T t$ pre $_{1}$ riboswitch by RNA solidphase synthesis, synthesized the $\mathrm{m}^{6} \mathrm{preQ}_{1}$ ligand, and for initial trials, incubated both in a riboswitch-typical aqueous buffer system $\left(2.5 \mu \mathrm{M}\right.$ RNA, $75 \mu \mathrm{M} \mathrm{m}{ }^{6} \mathrm{preQ}_{1}, 50 \mathrm{mM}$ MOPS, $100 \mathrm{mM}$ $\mathrm{KCl}, 2 \mathrm{mM} \mathrm{MgCl}_{2}, \mathrm{pH}$ 7.0). The reaction mixture was left overnight at room temperature, after which ultrafiltration with centrifugal concentrator devices was applied to remove the ligand and salts from the RNA for direct characterization by electrospray ionization (ESI) FT-ICR MS. Encouragingly, the high-resolution FT-ICR mass spectrum indeed showed the anticipated signal with a $14.0157 \mathrm{Da}$ mass increase, consistent with a methyl group 

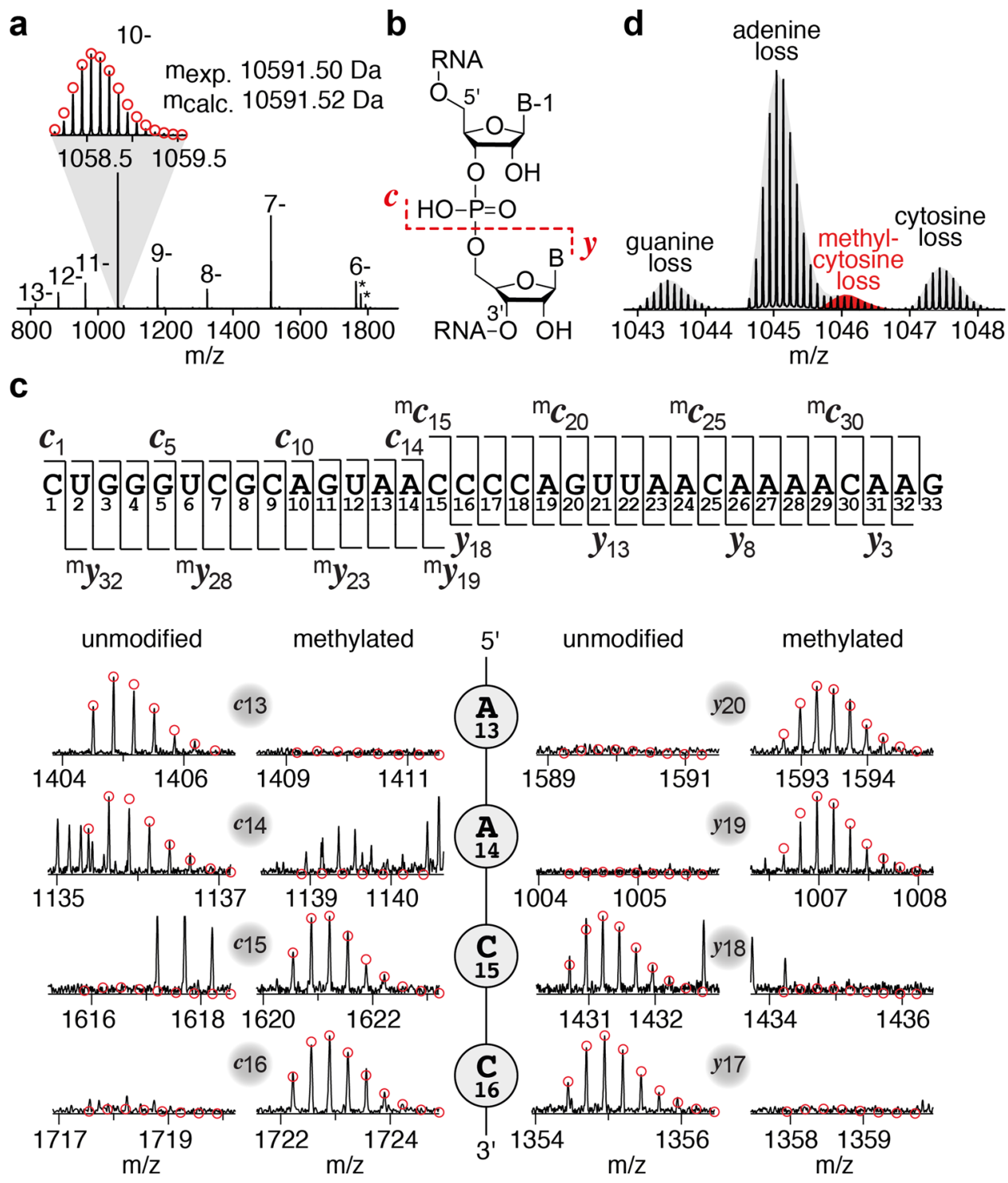

Fig. 3 FT-ICR mass spectrometric characterization of the methylated RNA product. a ESI mass spectrum of the $33 \mathrm{nt} \mathrm{m}^{3} \mathrm{C} T \mathrm{Tt}$ preQ${ }_{1}^{-I} \mathrm{RNA}$; the inset shows the isotopically resolved signal of the $(\mathrm{M}-10 \mathrm{H})^{10-}$ ions; asterisks indicate piperidine RNA adducts. $\mathbf{b}$ Collisionally activated dissociation (CAD) of $(\mathrm{M}-\mathrm{nH})^{\mathrm{n}-}$ ions of RNA in the collision cell produces $\mathrm{c}$ and $y$ fragment ions from RNA backbone cleavage. $\mathbf{c}$ Fragment-ion map illustrating sequence coverage from CAD of the methylated Tt preQ 1 -I RNA. The numbering of $\mathrm{c}$ and $y$ fragments starts from the $5^{\prime}$ and $3^{\prime}$ terminus, respectively (top). MS signals of unmodified and methylated $c_{13}, c_{14}, c_{15}, c_{16}$, and complementary $y_{20}, y_{19}, y_{18}, y_{17}$ fragments from CAD of $(M-7 H)^{7-}$ and $(M-10 H)^{10-}$ ions reveal the site of methylation (C15); the calculated isotopic profiles for unmodified and singly methylated RNA are indicated by red open circles. $\mathbf{d}$ Loss of methylated cytosine (red) in spectra from collisionally activated dissociation (CAD) of $(M-10 H)^{10-}$ ions of RNA is direct evidence for $C$ nucleobase methylation; the 1:3 ratio of $\mathrm{m}^{3} \mathrm{C} / \mathrm{C}$ nucleobase losses is consistent with destabilization of the glycosidic bond as a result of methylation at the N3 position.

attached to the RNA (Fig. 3a). The power of FT-ICR mass spectrometry is further manifested in the fact that backbone cleavage by collisionally activated dissociation (CAD) produced a complete set of $c$ and $y$ fragments (Fig. 3b,c) that allowed for sequence determination (Fig. 3c). The fragment mass values unequivocally revealed the site of methylation at the $\mathrm{C} 15$ nucleoside. Furthermore, the loss of methyl-C from RNA ions (Fig. 3d) is direct evidence that the methyl group is located at the nucleobase. With respect to the precise position, the observed ratio for $\mathrm{C}$ to methyl-C of 3:1, which is higher than the statistical ratio of $8: 1$ according to the number of $C s$ in the sequence, suggests the $\mathrm{N} 3$ atom because methylation at the imino group generates a positive charge that weakens the glycosidic bond and in consequence facilitates base loss.

To be able to rapidly analyze the methylation reaction, we optimized anion-exchange HPLC conditions, resulting in clear baseline separation of the methylation product from the unmodified RNA (Fig. 4a). We then tested different reaction conditions. Most importantly, when we decreased the $\mathrm{pH}$ from 7.0 to 6.0 , the reaction yields increased to a significant extent, approaching $50 \%$ after $24 \mathrm{~h}$ which is the maximum yield possible, considering that the cognate preQ $_{1}$ ligand (with low nanomolar affinity) 21,28 released during the methylation reaction will be bound by the riboswitch/ribozyme, thereby blocking the binding of $\mathrm{m}^{6}$ preQ $_{1}$ (Fig. $4 \mathrm{~b}$ and Supplementary Fig. 1a). We note that upon removal of the low molecular weight compounds by ultrafiltration, followed by adding a new batch of $\mathrm{m}^{6}$ preQ $_{1}$ the reaction yields were increased further (Supplementary Fig. 1a). Importantly, the reaction rate was dependent on $\mathrm{m}^{6} \mathrm{preQ}_{1}$ concentration, with an apparent Michaelis constant $K_{\mathrm{m}}$ of about $230 \mu \mathrm{M}$ (Fig. 4c and Supplementary Fig. 1b). In this context, we mention that when a one-fold excess of $\mathrm{m}^{6}$ preQ $_{1}$ over RNA was 
a
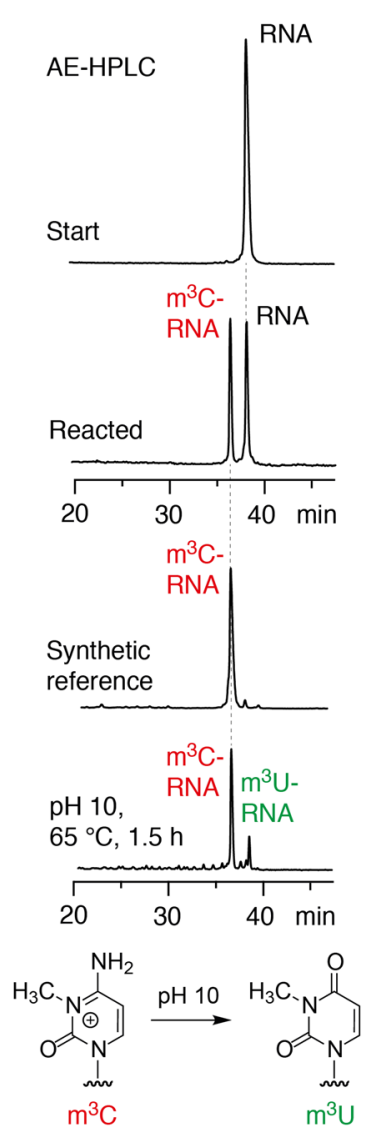

f

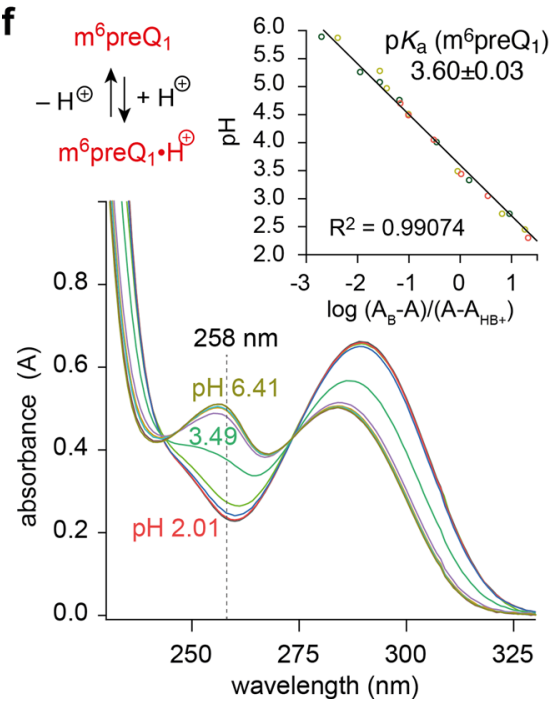

b

C
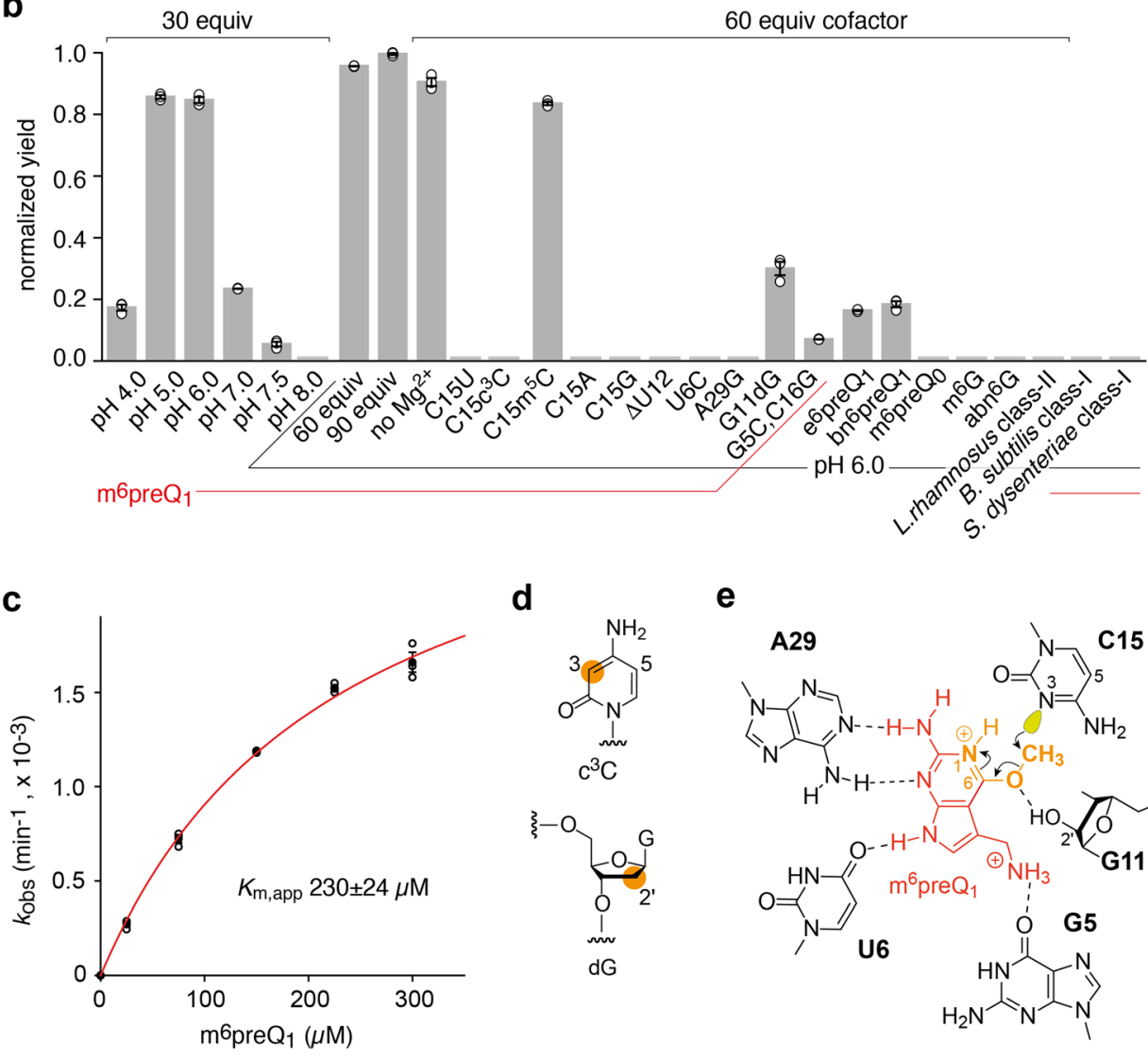

d<smiles></smiles>

g

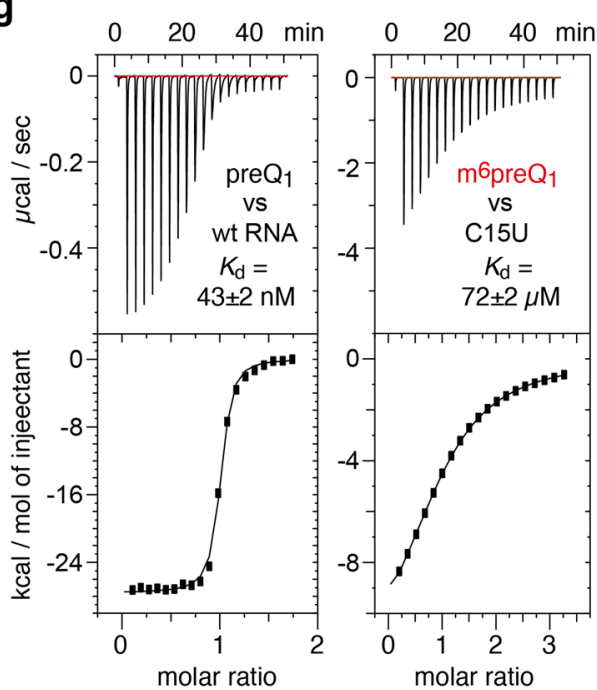

h<smiles></smiles><smiles></smiles><smiles>COc1nc(N)nc2[nH]cnc12</smiles>

applied only, methylation yields still amounted to 25\% (Supplementary Fig. 1b).

To unequivocally confirm the site of methylation, we synthesized $\mathrm{m}^{3} \mathrm{C}$ phosphoramidite for RNA solid-phase synthesis and prepared the corresponding $\mathrm{m}^{3} \mathrm{C} 15$ containing RNA reference (Fig. 4a). This RNA had the same retention time as the product obtained by methylation using $\mathrm{m}^{6} \mathrm{preQ}_{1}$. We further point out that the synthetic $\mathrm{m}^{4} \mathrm{C} 15$ and $\mathrm{m}^{5} \mathrm{C} 15$ RNA references had retention times that were undistinguishable from the unmodified RNA in our HPLC assay (Supplementary Fig. 1c). Therefore, we separated the $\mathrm{m}^{3} \mathrm{C}$ RNA product from a methylation reaction mixture and analyzed the remaining RNA by FT-ICR mass spectrometry, but no further methylation products were detected (Supplementary Fig. 1d). Furthermore, we exposed the isolated $\mathrm{m}^{3} \mathrm{C} 15 \mathrm{RNA}$ to harsh basic conditions ( $\mathrm{pH}$ 10) and observed the expected $\mathrm{m}^{3} \mathrm{C}$-to- $\mathrm{m}^{3} \mathrm{U}$ conversion product (beside emerging fragments from RNA degradation) which additionally confirms that $\mathrm{m}^{3} \mathrm{C} 15 \mathrm{RNA}$ was formed selectively (Fig. 4a and Supplementary Fig. 1e).

RNA sequence requirements and reaction mechanism. Next, we set out to investigate the $T t \mathrm{preQ}_{1}$ class I riboswitch sequence requirements for methyl group transfer. We observed no 
Fig. 4 Reactivity scope of the $\mathbf{T t}$ preQ $\mathbf{Q}_{\mathbf{1}}-\mathbf{I}$ riboswitch scaffold. a Anion-exchange $H P L C$ analysis of the preQ ${ }_{1}-I R A$-catalyzed reaction with $\mathrm{m}^{6} \mathrm{preQ}_{1}$ at $37^{\circ} \mathrm{C}_{\text {; }}$ $2.5 \mu \mathrm{M}$ RNA substrate, $225 \mu \mathrm{M} \mathrm{m}^{6} \mathrm{preQ}_{1}, 2.0 \mathrm{mM} \mathrm{MgCl}_{2}$, pH 6.0. HPLC traces of unmodified RNA, the reacted mixture, and the corresponding $\mathrm{m}^{3} \mathrm{C}$-modified synthetic RNA reference is shown for comparison (for reaction time course see Supplementary Fig. $1 \mathrm{~b}$ ). The $\mathrm{m}^{3} \mathrm{C}$-modified RNA elutes earlier. Incubation of $\mathrm{m}^{3} \mathrm{C}$ preQ $\mathrm{Q}_{1}$-I RNA (isolated from a typical methylation reaction with $\mathrm{m}^{6} \mathrm{preQ}_{1}$ ) under harsh basic conditions produced $\mathrm{m}^{3} \mathrm{U}$ from $\mathrm{m}^{3} \mathrm{C}$ under concomitant $\mathrm{RNA}$ hydrolysis (for FT-ICR MS characterization of $\mathrm{m}^{3} \mathrm{U}$-RNA see Supplementary Fig. 1e); chemical structures of $\mathrm{m}^{3} \mathrm{C}$-to- $\mathrm{m}^{3} \mathrm{U}$ hydrolysis. $\mathbf{b}$ preQ $\mathrm{Q}_{1}-\mathrm{I} R \mathrm{RN}$ reactivity analysis using diverse buffer conditions, nucleobase mutagenesis, atomic mutagenesis, and near-cognate cofactors; bars (gray) show mean \pm s.e.m. $(n=3$ independent experiments); HPLC traces are depicted in Supplementary Fig. 2, 3; source data are provided in the Source Data file. c The reaction rate is dependent on $\mathrm{m}^{6} \mathrm{preQ}_{1}$ concentration. The observed rate constants $k_{\text {obs }}$ were determined based on $\mathrm{HPLC}$ trace analysis at five concentrations of $\mathrm{m}^{6}$ preQ $\mathrm{Q}_{1}$ ranging from 25 to $300 \mu \mathrm{M}$. The red line represents a curve fit to $k_{\mathrm{obs}}=k_{\max }\left[\mathrm{m}^{6} \mathrm{preQ}_{1}\right] /\left(K_{\mathrm{m}, \mathrm{app}}+\left[\mathrm{m}^{6} \mathrm{preQ} \mathrm{Q}_{1}\right]\right.$ ). Individual data points (open circles) ( $n=3$ independent experiments), mean \pm s.e.m. (black circles); source data are provided in the Source Data file. $\mathbf{d}$ Chemical structures for $\mathrm{c}^{3} \mathrm{C}$ and $\mathrm{dG}$ used in atomic

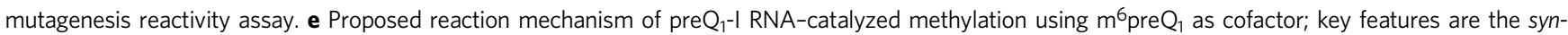
conformation of the methyl iminoester moiety and $\mathrm{N} 1$ protonation of $\mathrm{m}^{6} \mathrm{preQ}_{1}$; furthermore, coordination of the $2^{\prime}-\mathrm{OH} \mathrm{G}_{11}$ to $\mathrm{O}^{6}$ of $\mathrm{m}^{6}$ preQ $\mathrm{Q}_{1}$ assists in cofactor alignment and contributes to improve leaving group quality. $\mathbf{f} U V$-spectroscopic determination of the $p K_{a}$ value of $m^{6} p r e Q_{1}(n=3$ independent experiments); source data are provided in the Source Data file. $\mathbf{g}$ Representative isotherm and 'One set of sites' bindingmodel fit for the preQ $Q_{1}$ class I riboswitch titrated with $\mathrm{preQ}_{1}$ (left) and $\mathrm{m}^{6} \mathrm{preQ}_{1}$ (right); the indicated $K_{\mathrm{d}}$ values were determined at $\mathrm{pH} 6$ ( $n=3$ independent experiments); source data are provided in the Source Data file; one experiment for pre $Q_{1}$ is depicted (left): $N=0.97, K_{A}=2.37 \times 10^{7} \mathrm{M}^{-1}, \Delta H=-27.57 \times 10^{3} \mathrm{cal} \mathrm{mol}^{1}$, and $\Delta S=-58.7 \mathrm{cal}\left(\mathrm{mol} \mathrm{K}\right.$ ) ${ }^{1}$; one experiment for $\mathrm{m}^{6} \mathrm{preQ}_{1}$ is depicted (right): $N=0.99, K_{\mathrm{A}}=1.36 \times 10^{4} \mathrm{M}^{-1}, \Delta H=-12.85 \times 10^{3} \mathrm{cal} \mathrm{mol}^{1}$, and $\Delta S=-24.2 \mathrm{cal}$ (mol K) $)^{1}$. h Chemical structures of other potential cofactors tested.

methylation products when $\mathrm{C} 15$ was mutated either to 3deazacytidine $\left(\mathrm{c}^{3} \mathrm{C}\right)$, U, A, or G (Fig. $4 \mathrm{~b}, \mathrm{~d}$ and Supplementary Fig. 2). In contrast, when $\mathrm{C} 15$ was mutated to 5-methylcytidine $\left(\mathrm{C} 15 \mathrm{~m}^{5} \mathrm{C}\right)$, methylation occurred almost as efficiently as for wildtype RNA (Fig. $4 \mathrm{~b}$ and Supplementary Fig. 2). Furthermore, when the bulged-out nucleotide U12 close to the binding site, was deleted (mutant $\Delta \mathrm{U} 12$ ), no methylation occurred (Fig. 4b). U12, therefore, seems essential for retaining the structural dynamics within the U12-A13-A14-C15 segment. Moreover, when U6 and A29 which are crucial for recognition of the N9-N3 face of preQ 1 and $\mathrm{m}^{6}$ preQ $\mathrm{Q}_{1}$ were mutated individually to $\mathrm{C}$ and $\mathrm{G}$, methylation was not observed anymore (Fig. $4 \mathrm{~b}$ and Supplementary Fig. 2). Importantly, compensatory mutation of the conserved base pair G5-C16 into C5-G16 gave a sevenfold decrease in yields for the $\mathrm{m}^{3} \mathrm{C}$-modified RNA (Fig. $4 \mathrm{~b}$ ), consistent with the crucial interaction of the $\mathrm{O}^{6}-\mathrm{G} 5$ atom and the protonated 7-aminomethyl group of $\mathrm{preQ}_{1}$ or $\mathrm{m}^{6} \mathrm{preQ}_{1}$. Strikingly, we found evidence for a potential role of the $2^{\prime}-\mathrm{OH}$ group of G11 in the methyl transfer reaction. When we deleted this functional group (dG11 mutant), reaction yields decreased to one-fourth compared to the wild-type RNA (Fig. 4b,d). This finding together with the above-described $\mathrm{pH}$ dependence of the reaction leads to the proposed reaction mechanism depicted in Fig. 4e. The favorable, slightly acidic $\mathrm{pH}$ value of 5-6 is consistent with saturating protonation of the 7aminomethyl group and its recognition by G5. Importantly, it is also consistent with protonation of $\mathrm{N1}$ of $\mathrm{m}^{6} \mathrm{preQ}_{1}$, thereby facilitating stabilization of the $\mathrm{preQ}_{1}$ leaving group (Fig. 4f). Our observation that methylation activity becomes impaired at $\mathrm{pH}$ values lower than 5 suggests protonation of $\mathrm{N} 3$ of $\mathrm{C} 15$, and hence the loss of nucleophilicity needed for an attack at $\mathrm{m}^{6}$ preQ $\mathrm{Q}_{1}$. Furthermore, the model is compatible with stabilization of the syn conformation of the methyl iminoester by a hydrogen bond between $\mathrm{m}^{6} \mathrm{preQ}_{1} \mathrm{O}^{6}$ and the $2^{\prime}-\mathrm{OH}$ of G11.

Finally, we set out to estimate the affinity of $\mathrm{m}^{6} \mathrm{preQ}_{1}$ to the riboswitch. Using isothermal titration calorimetry (ITC), we first determined the dissociation constant of the cognate $\mathrm{pre}_{1}$ ligand to wildtype $\mathrm{preQ}_{1}$ RNA at $\mathrm{pH} 6$ as reference (Fig. $4 \mathrm{~g}$ ). The $K_{\mathrm{d}}$ ITC value amounted to $43.0 \pm 1.9 \mathrm{nM}$. We then determined the affinity of $\mathrm{m}^{6} \mathrm{preQ}_{1}$ to the unreactive C15U RNA mutant and obtained a $K_{\mathrm{d}}$ ITC value of $72.2 \pm 2.1 \mu \mathrm{M}$ at $\mathrm{pH}$ 6.0. This micromolar $K_{\mathrm{d}}$ likely reflects the portion of pairing strength that arises from the identical recognition of the $\mathrm{C} 7-\mathrm{CH}_{2} \mathrm{NH}_{2}$ moieties and the $\mathrm{N} 9-\mathrm{N} 3-\mathrm{C} 2-\mathrm{NH}_{2}$ faces of $\mathrm{preQ}_{1}$ and $\mathrm{m}^{6} \mathrm{preQ}_{1}$, respectively, by the pocket through A29 and U6. We note that A29G and U6C mutants were both inactive (Supplementary Fig. 2).
Further, we believe that the actual affinity of $\mathrm{m}^{6} \mathrm{preQ}_{1}$ to wildtype (C15) RNA is higher than to the unreactive C15U mutant because the imino tautomer ${ }^{\mathrm{im}} \mathrm{C} 15$ as proposed in Fig. $2 \mathrm{f}$ could in principle provide a better match with respect to hydrogen donoracceptor interactions compared to U15.

Near-cognate cofactors and other pre $_{1}$ riboswitch scaffolds. Encouraged by our finding that a simple, methylated nucleobase can act as cofactor for riboswitch methylation, we set out to synthesize and test structural congeners of $\mathrm{m}^{6} \mathrm{preQ}_{1}$, namely $O^{6}$ ethyl-preQ ${ }_{1}\left(e^{6}\right.$ preQ $\left._{1}\right), O^{6}$-benzyl-preQ ${ }_{1}\left(b^{6}\right.$ preQ $\left._{1}\right)$, and $O^{6}$ methyl-preQ ${ }_{0}\left(\mathrm{~m}^{6}\right.$ preQ $\left._{\mathrm{o}}\right)$ (Fig. $4 \mathrm{~h}$ and Supplementary Fig. 3). These derivatives, however, exhibited only very minor-or noalkylation activities under optimized conditions (Fig. $4 \mathrm{~b}$ and Supplementary Fig. 1f,g and Supplementary Fig. 3). Of further note, $O^{6}$-methylguanine $\left(\mathrm{m}^{6} \mathrm{G}\right)$ and $O^{6}$-(4-aminomethyl)benzylguanine $\left(a b n^{6} \mathrm{G}\right)$ did not result in detectable amounts of $\mathrm{m}^{3} \mathrm{C} 15$ RNA product (Fig. 4b). The observation that the potential methyl group donors $\mathrm{m}^{6} \mathrm{G}$ and $\mathrm{m}^{6} \mathrm{preQ}_{0}$ did not transfer their methyl groups can be rationalized by considering the significantly lower affinities of their non-methylated precursors, preQ $_{0}$ (17-fold lower) ${ }^{22}$ and $\mathrm{G}$ (at least 25 -fold lower ${ }^{29}$ compared to the cognate ligand $\mathrm{preQ}_{1}$. Therefore, it is reasonable to assume that $\mathrm{m}^{6} \mathrm{preQ}_{1}$ is also significantly stronger bound compared to $\mathrm{m}^{6} \mathrm{G}$ and $\mathrm{m}^{6} \mathrm{preQ}_{0}$. It is the 7-aminomethyl substituent of $\mathrm{preQ}_{1}$ and $\mathrm{m}^{6}$ preQ $_{1}$ that has to be present together with its interaction partner, the G5-C16 base pair to reach high affinities ${ }^{22}$ and high methylation yields (see G5C-C16G mutant, Fig. 4b). We further note that $e^{6}$ preQ $_{1}$ and $b^{6}{ }^{6}{ }^{2} Q_{1}$ which provide the 7aminomethyl substituent exhibit lower yields likely because of steric hindrance of their larger $O^{6}$ substituents with the binding pocket.

Next, we were wondering if representatives of the other known preQ $_{1}$ riboswitch classes also possess self-methylation properties $^{29}$. Both, preQ $_{1}$ class II and III riboswitches have an identical architecture of their preQ $_{1}$-bound pockets, however, this pocket architecture is different from class $\mathrm{I}^{30,31}$. Characteristically, class II and III apply a preQ ${ }_{1}-\mathrm{C}$ trans base pair instead of a cis Watson-Crick pair (class I), and significantly, the $O^{6}$ atom of preQ $_{1}$ is rather solvent-exposed with no obvious RNA functionalities for nucleophilic attack nearby. Nevertheless, we tested the well-studied preQ $_{1}$ II riboswitch from Lactobacillus rhamnosus for methyl transfer of $\mathrm{m}^{6} \mathrm{preQ}_{1}$; as expected, methylation was not observed (Fig. 4b). 
Noteworthily, class I preQ ${ }_{1}$ riboswitches are categorized into three subtypes, with the $T t$ riboswitch belonging to type $1^{29}$. We, therefore, complemented our analysis of RNA sequence requirements with a type 2 (Bacillus subtilis) and a type $3 \mathrm{preQ}_{1}$ riboswitch (Shigella dysenteriae). Both revealed no methyltransferase activity (Fig. 4b).

\section{Discussion}

Our study answers the long-standing question of whether contemporary riboswitches can act as cofactor-dependent ribozymes by a clear yes. Direct evidence became possible after careful analysis of three-dimensional riboswitch architectures in combination with rational ligand design and chemical intuition that finally led to the discovery of methyltransferase activity of the $T t$ $\mathrm{preQ}_{1}$ class I riboswitch. PreQ $\mathrm{Q}_{1}$ itself is a guanine-derived precursor of the nucleobase queuosine $(\mathrm{Q})$ that is found in the wobble position of tRNAs containing the GUN anticodon ${ }^{32}$. The presence of $\mathrm{Q}$ in tRNAs improves their ability to read degenerate codons, while the absence of enzymes participating in $\mathrm{Q}$ biosynthesis or salvage results in deleterious phenotypes in many organisms $s^{33,34}$. Noteworthily, $\mathrm{O}^{6}$-methylated versions of the pre-queuosine heterocycle have been found in nature, in form of 2-amino-5-cyano-4-methoxypyrrolo[2,3-d]pyrimidine produced by Streptomyces ${ }^{35}$, and as the corresponding $N^{2}$-glyosylated natural products huimycin and dapiramicin ${ }^{36}$. Their occurrence hints at potential cellular availability of the nearcognate ligand $\mathrm{m}^{6} \mathrm{pre}_{1}$ for $\mathrm{pre}_{1}$ riboswitches. In this context it is also interesting that $\mathrm{preQ}_{1}$ and $\mathrm{SAM}$ aptamers have been found in a putative tandem riboswitch architecture which might hint at the regulatory utility of linking $\mathrm{m}^{6} \mathrm{preQ}_{1}$ biosynthesis to the concentrations of SAM and pre $\mathrm{Q}_{1}{ }^{29,35,36}$. At this time, one can only speculate about the biological relevance of a riboswitch with potential self-methylation activity. Such a scenario implies that $\mathrm{m}^{3} \mathrm{C}$ methylation in the riboswitch pocket impairs recognition of the cognate ligand $\mathrm{pre}_{1}$ and thereby impacts the gene regulatory function of the riboswitch. Thus far, the $\mathrm{m}^{3} \mathrm{C}$ modification itself is known for tRNAs in position 32 in diverse organisms ${ }^{37,38}$, ranging from yeast ${ }^{39}, S$. Pombe $e^{40}$, parasites such as Trypanosoma bruce $^{41}$, to mice, rat, and human ${ }^{42}$. The modification has attracted additional interest when $\mathrm{m}^{3} \mathrm{C}$ has been identified as dynamic modification also in $\mathrm{mRNA}$, and corresponding writer (METTL2, METTL6, METTL8) and eraser enzymes (ALKBH1, ALKBH3) have been characterized ${ }^{43}$. The emerging importance of the modification stimulated the development of novel RNA sequencing approaches, AlkAniline-Seq ${ }^{44}$ and HAC-seq ${ }^{45}$, respectively, to reveal $\mathrm{m}^{3} \mathrm{C}$ sites transcriptome-wide.

We furthermore anticipate that the discovered methyltransferase activity of the $\mathrm{preQ}_{1}$ class I riboswitch can serve as starting point for engineering in vitro and in vivo methylation tools. Applications for $\mathrm{m}^{3} \mathrm{C}$ installation are conceivable not only in cis, but also in trans. First experimental attempts towards this aim by splitting the aptamer into two halves have been successful and led to remarkable $38 \%$ of methylation for the $\mathrm{preQ}_{1}$ stemloop by simply adding the $3^{\prime}$-terminal pre $\mathrm{Q}_{1}$ RNA fragment in the presence of cofactor (Fig. 5). Beyond methyltransferase activity and the particular $\mathrm{m}^{3} \mathrm{C}$ modification investigated here, our work may stimulate the search for other ribozyme-catalyzed reactions that are lying dormant in present-day riboswitches. Given the large number and great diversity of riboswitches that have been identified to date, a broad repertoire of chemical reactivities should be directly retrievable without the need for nucleic acids evolution that builds on constructed RNA libraries of naturally occurring riboswitch scaffolds ${ }^{46}$ or on de novo in vitro RNA selection approaches ${ }^{47}$.
Finally, we stress the importance of our findings for the RNA world hypothesis which postulates that possible early life on Earth relied on catalytic RNA properties essential for evolving sophisticated RNA-based life ${ }^{5-10,48}$. The idea is strongly supported by the original discovery of bacterial riboswitches that regulatewithout the aid of proteins-the expression of genes that are involved in the biosynthesis of metabolites ${ }^{6}$. Some of these riboswitches may have evolved from ancient cofactor-dependent ribozymes preserving their regulatory capacity while the reactivity part has been taken over by more efficient protein enzyme machineries. Our findings may also hint at a prebiotic version of RNA epigenetics with methylated nucleobases taking the role as cofactors for ancient methyltransferase ribozymes ${ }^{49-52}$.

\section{Methods}

RNA synthesis. RNA oligonucleotides were prepared by solid-phase synthesis using phosphoramidite chemistry $\left(2^{\prime}-O\right.$-TOM-protected) on controlled-pore glass solid supports ${ }^{53}$. RNA sequences are given in Supplementary Table 1. Modified phosphoramidites for atomic mutagenesis and reference oligonucleotides were purchased (ChemGenes, Glen Research, Berry Asscociates) or prepared in-house, following published procedures ${ }^{54,55}$. RNA oligonucleotides were deprotected with ammonia and butylamine instead of ammonia and methylamine to avoid any possible methylated RNA from deprotection, followed by $1 \mathrm{M}$ tetrabutylammonium fluoride in THF, desalted (Sephadex G25), and purified by denaturing anion exchange chromatography (Dionex DNAPac PA100, $9 \times 250$ $\mathrm{mm}$, at $80^{\circ} \mathrm{C}$; solvent A was $25 \mathrm{mM}$ Tris- $\mathrm{HCl}(\mathrm{pH} 8.0)$ and $20 \mathrm{mM} \mathrm{NaClO}_{4}$ in $20 \%$ aqueous acetonitrile; solvent $\mathrm{B}$ was $25 \mathrm{mM}$ Tris- $\mathrm{HCl}(\mathrm{pH} 8.0)$ and $0.6 \mathrm{M} \mathrm{NaClO}_{4}$ in $20 \%$ aqueous acetonitrile; the gradient was: linear, $25-40 \%$ (25-45 for longer sequences) with slope of $5 \%$ solvent B per column volume). Customized deprotection conditions were used for $\mathrm{m}^{3} \mathrm{C}$ RNA $\left(3: 1\right.$ (v/v) 28-30\% aqueous $\mathrm{NH}_{3}$ and $\mathrm{EtOH}$, at $40^{\circ} \mathrm{C}$ for $\left.5 \mathrm{~h}\right), \mathrm{m}^{4} \mathrm{C}$ RNA $\left(\mathrm{O}^{4}\right.$-chlorophenyl $\mathrm{U}$ convertible nucleoside approach, $7 \mathrm{M} \mathrm{NH}_{3}$ in $\mathrm{MeOH}$ at $42^{\circ} \mathrm{C}$ for $18 \mathrm{~h}$ ). The quality of RNAs (purity and identity) was analyzed by anion-exchange HPLC (Dionex DNAPac PA100, $2 \times 250$ $\mathrm{mm}$, eluents as above, the gradient was: linear, $22-35 \%$ solvent B, with slope of $0.87 \%$ solvent B per column volume), and HR-ESI-MS (Thermo Fisher Orbitrap, negative-mode) or FT ICR MS (see below). Measured and calculated masses are listed in Supplementary Table 1.

Characterization of $\mathbf{m}^{6}$ preQ $_{1}, e^{6} \mathbf{p r e Q}_{1}$, and $\mathbf{b n}^{6} \mathbf{p r e Q}_{\mathbf{1}}$. Analytical data (NMR spectra) of $\mathrm{m}^{6}$ pre $_{1}, \mathrm{e}^{6} \mathrm{preQ}_{1}$, and $\mathrm{bn}^{6} \mathrm{preQ}_{1}$ are shown in Supplementary Figs. 4-11. $\mathrm{m}^{6} \mathrm{G}$ and $\mathrm{abn}^{6} \mathrm{G}$ were purchased from commercial sources (Carbosynth).

Reaction of preQ $\mathbf{Q}_{\mathbf{1}}$ RNA with $\mathbf{m}^{\mathbf{6}}$ preQ $_{\mathbf{1}}$ or analogs. A typical methylation reaction was carried out in a volume of $200 \mu \mathrm{l}$ containing $0.5 \mathrm{nmol}$ RNA $(2.5 \mu \mathrm{M})$ and $75 \mu \mathrm{M}$ ligand (30 equiv) in buffer solution $\left(2 \mathrm{mM} \mathrm{MgCl}_{2}, 100 \mathrm{mM} \mathrm{KCl}, 50 \mathrm{mM}\right.$ 2-( $N$-morpholino) ethanesulfonic acid (MES), $\mathrm{pH}$ 6.0). After heating the mixture to $90^{\circ} \mathrm{C}$ for $2 \mathrm{~min}$, it was incubated for $48 \mathrm{~h}$ at $37^{\circ} \mathrm{C}$. After desalting using a Sep-Pak $\mathrm{C} 18$ cartridge, the methylated RNA product was directly analyzed in the mixture or isolated by AE HPLC, desalted again (Sep-Pak C18), and subjected to FT ICR-ESIMS (which included a further desalting step using centrifugal concentrators; see below). For experiments at pH 4 and 5, sodium acetate buffer was used instead of MES; for $\mathrm{pH} 7,7.5$, and 8, MOPS was used. Several of the experiments were additionally analyzed using 60 and 120 equiv of the cofactor.

The hydrolysis of $\mathrm{m}^{3} \mathrm{C}$ to $\mathrm{m}^{3} \mathrm{U}$ RNA was examined in a volume of $280 \mu \mathrm{l}$ with 7 nmol RNA $(25 \mu \mathrm{M})$ in $25 \mathrm{mM} \mathrm{Na}_{2} \mathrm{CO}_{3}$ buffer $(\mathrm{pH} 10)$ with $1 \mathrm{mM}$ EDTA at $65^{\circ} \mathrm{C}$ for $1.5 \mathrm{~h}$. After desalting (Sep-Pak C18) the $\mathrm{m}^{3} \mathrm{U}$ RNA was isolated by AE HPLC and analyzed by FT ICR-ESI-MS (see below).

FT-ICR mass spectrometric analysis of RNA methylation/alkylation products Methanol was HPLC grade (Acros), ammonium acetate ( $\geq 99.0 \%, \mathrm{Na} \leq 5 \mathrm{mg} / \mathrm{kg}$, $K \leq 5 \mathrm{mg} / \mathrm{kg}$ ), piperidine ( $\geq 99.5 \%)$, and imidazole $(\geq 99.5 \%, \mathrm{Na} \leq 50 \mathrm{mg} / \mathrm{kg}, K \leq$ $50 \mathrm{mg} / \mathrm{kg}$ ) were from Sigma-Aldrich, and $\mathrm{H}_{2} \mathrm{O}$ was purified to $18 \mathrm{M} \Omega \cdot \mathrm{cm}$ at room temperature using a Milli-Q system (Millipore). Experiments were performed on a 7T Fourier transform ion cyclotron resonance (FT-ICR) mass spectrometer (Bruker APEX ultra) equipped with an ESI source for $(\mathrm{M}-n \mathrm{H})^{\mathrm{n}-}$ ion generation and a collision cell through which a flow of Ar gas was maintained for CAD. The mass resolving power of this instrument is routinely (broadband detection, $2 \mathrm{M}$ data points for $\mathrm{a} \sim 2 \mathrm{~s}$ transient) $\sim 220,000, \sim 120,000$, and $\sim 80000$ at $\mathrm{m} / z 500$, 1000 , and 1500 , respectively, and the mass accuracy is $\sim 1 \mathrm{ppm}$ with internal calibration and $\sim 20 \mathrm{ppm}$ with external calibration (Supplementary Table 1). RNA was electrosprayed (flow rate $1.5 \mu \mathrm{l} / \mathrm{min}$ ) from $1-2 \mu \mathrm{M}$ solutions in $1: 1$ or 9:1 $\mathrm{H}_{2} \mathrm{O} / \mathrm{CH}_{3} \mathrm{OH} \mathrm{vol} / \mathrm{vol}$ with piperidine $(2-10 \mathrm{mM})$ and imidazole $(0-10 \mathrm{mM})$ as additives. Prior to dissociation by $\mathrm{CAD}$, the $(\mathrm{M}-n \mathrm{H})^{n-}$ ions under study were isolated in a linear quadrupole; for a more detailed description of the experimental setup for CAD see ${ }^{56}$. For statistical reasons, between 25 and 500 scans 
a

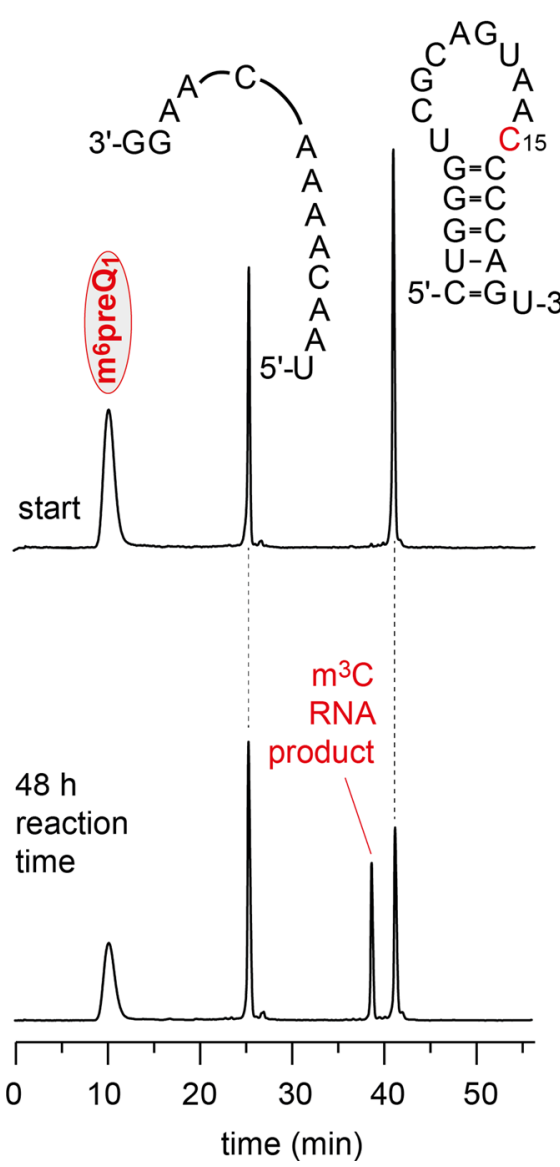

b

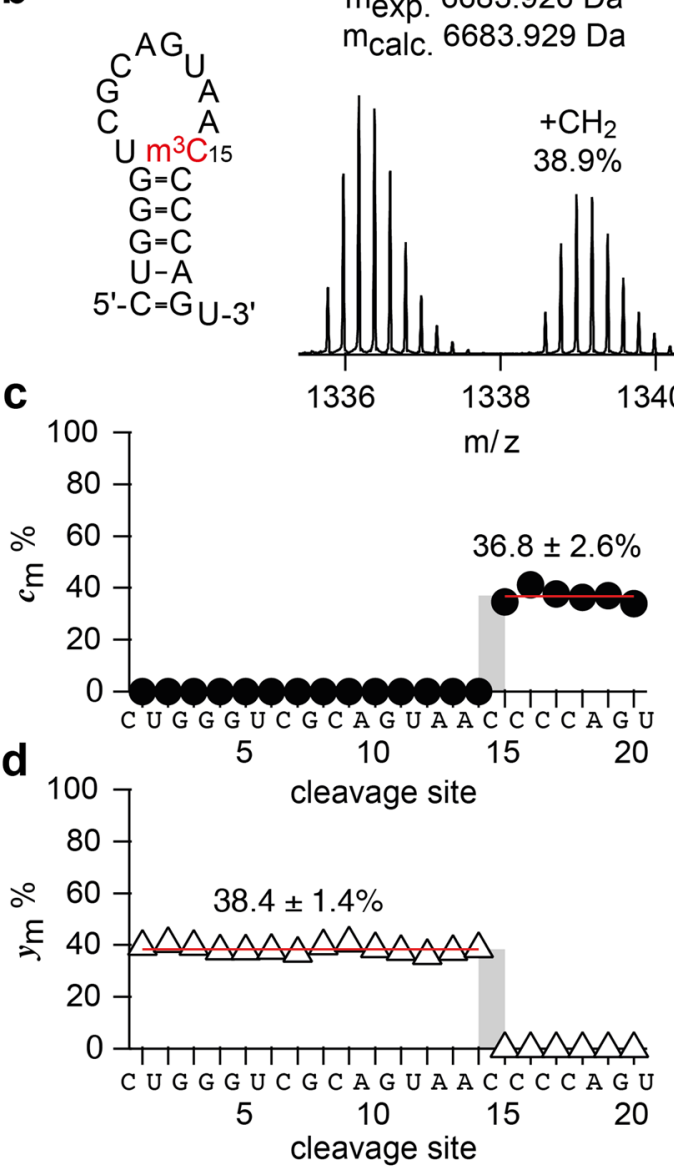

Fig. 5 Methyltransferase activity using a split aptamer of preQ $\mathbf{Q}_{\mathbf{1}}$-I RNA. a Sequences of the two $T t \mathrm{preQ}_{1}-\mathrm{I}$ fragments used and anion-exchange $\mathrm{HPLC}$ traces of the reaction mixture at time points 0 and $48 \mathrm{~h}\left(25 \mu \mathrm{M}\right.$ each RNA strand, $1.5 \mathrm{mM} \mathrm{m}^{6} \mathrm{preQ}_{1}, 2.0 \mathrm{mM} \mathrm{MgCl}, 100 \mathrm{mM} \mathrm{KCl}, \mathrm{MES}^{2}$ buffer pH $\left.6.0,37^{\circ} \mathrm{C}\right)$; as expected, the $\mathrm{m}^{3} \mathrm{C}$-modified RNA product elutes earlier. $\mathbf{b}$ Secondary structure of the $\mathrm{m}^{3} \mathrm{C}$-modified preQ $_{1}$-stem-loop RNA and CAD-MS of co-isolated $(\mathrm{M}-5 \mathrm{H})^{5-}$ ions of unreacted $21 \mathrm{nt}$ RNA $\left(61.1 \%, m_{\text {exp. }} 6683.926 \mathrm{Da}, m_{\text {calc. }} 6683.929 \mathrm{Da}\right)$ and methylated RNA $\left(38.9 \%, m_{\text {exp. }} 6697.942, m_{\text {calc. }} 6697.945 \mathrm{Da}\right)$ produced at $65 \mathrm{eV}$ laboratory frame energy $\mathrm{c}$ and $\mathrm{y}$ fragments with and without methylation. c Thereby, the fraction of methylated $c$ fragments $\left(c_{\mathrm{m}}\right.$ ) increased from $0 \%$ to $36.8 \pm 2.6 \%$ at site 15 (mean of values for sites 15 to $20 \pm$ standard deviation). $\mathbf{d}$ The fraction of methylated $y$ fragments ( $y_{\mathrm{m}}$ ) decreased from $38.4 \pm 1.4 \%$ to $0 \%$ at site 15 (mean of values for sites 1 to $14 \pm$ standard deviation), which both are consistent with C15 as methylation site and with the yields independently obtained by HPLC analysis. Source data are provided in the Source Data file.

were added for each spectrum (20-50 for ESI, 100-500 for CAD), and data reduction utilized the SNAP2 algorithm (Bruker). For desalting, $400 \mu \mathrm{l}$ of an ammonium salt solution $\left(100 \mathrm{mM}\right.$ ammonium acetate in $\left.\mathrm{H}_{2} \mathrm{O}\right)$ was added to $100 \mu \mathrm{l}$ RNA solution (about $1 \mathrm{nmol}$ in $\mathrm{H}_{2} \mathrm{O}$ ) and concentrated to $100 \mu \mathrm{l}$ using Vivaspin 500 centrifugal concentrators (Sartorius, MWCO 3000). The process was repeated five to seven times, followed by six to seven cycles of concentration and dilution with $\mathrm{H}_{2} \mathrm{O}$. RNA concentration was determined by UV absorption at $260 \mathrm{~nm}$ using a NanoPhotometer (Implen).

Kinetic assays of RNA-catalyzed methylation reactions. The methylation reactions were carried out as described above (on a $1.5 \mathrm{nmol}$ scale; $600 \mu \mathrm{l}$ reaction volume) and $50-\mu \mathrm{l}$ aliquots were taken at desired time points and quenched immediately by adding $50 \mu \mathrm{l}$ of stop solution (12 M urea). The samples were analyzed by AE HPLC and UV-detection. The peak areas were quantified. The yield versus time data were fit to (fraction unreacted) $=Y\left(1-\mathrm{e}^{-k t}\right)$, in which $k=k_{\mathrm{obs}}$ and $Y=$ final yield, using OriginPro (2020). All kinetic assays were carried out as three independent replicates.

Isothermal titration calorimetry (ITC). ITC measurements were performed on a MicroCal iTC 200 instrument at $20^{\circ} \mathrm{C}$ in $50 \mathrm{mM}$ MES, $100 \mathrm{mM} \mathrm{KCl}$ and $2 \mathrm{mM}$ $\mathrm{MgCl}_{2}$ (pH 6.0). For $\mathrm{preQ}_{1}$, the concentration of Tte preQ $_{1}$ class I RNA in the measuring cell was typically $0.012 \mathrm{mM}$; preQ $Q_{1}$ ligand was in the syringe at a concentration that was 10 -fold higher than the RNA. The c-value was typically around 300 . For $\mathrm{m}^{6} \mathrm{preQ}_{1}$, the concentration of the Tte $\mathrm{preQ}_{1}$ class I RNA in the measuring cell was typically $0.19 \mathrm{mM} ; \mathrm{m}^{6} \mathrm{preQ}_{1}$ cofactor was in the syringe at a concentration that was 15 -fold higher than the RNA. The $c$-value was typically around 3. Both $K_{\mathrm{d}}$ determinations were carried out as three independent replicates.
Reporting summary. Further information on research design is available in the Nature Research Reporting Summary linked to this article.

\section{Data availability}

All relevant data are available from the corresponding author on reasonable request. Source data for calculation of errors in Figs. 4b, 4c, 4f, 4g, 5a, 5c, and $5 \mathrm{~d}$ and Supplementary Fig. 1b, are provided as a Source Data file.

\section{Code availability}

Custom software that would need code availability was not used for this study. Software used for data collection: Bruker Daltronics Compass Apex Control 3.0.0, Bruker Topspin 3.6, UNICORN 5.0, Chromeleon 6.8. Software used for data analysis: Microsoft Excel 16.16.22, OriginPro 2020.

Received: 3 February 2021; Accepted: 4 June 2021; Published online: 23 June 2021

\section{References}

1. Breaker, R. R. Imaginary ribozymes. ACS Chem. Biol. 15, 2020-2030 (2020).

2. Cochrane, J. C. \& Strobel, S. A. Riboswitch effectors as protein enzyme cofactors. RNA 14, 993-1002 (2008). 
3. Micura, R. \& Höbartner, C. Fundamental studies of functional nucleic acids: aptamers, riboswitches, ribozymes and DNAzymes. Chem. Soc. Rev. 49, 7331-7353 (2020).

4. Joyce, G. F. \& Szostak, J. W. Protocells and RNA self-replication. Cold Spring Harb. Perspect. Biol. 10, a034801 (2018).

5. Nelson, J. W. \& Breaker, R. R. The lost language of the RNA World. Sci. Signal. 10, eaam8812 (2017).

6. Jadhav, V. R. \& Yarus, M. Coenzymes as coribozymes. Biochimie 84, 877-888 (2002).

7. Kirschning, A. Coenzymes and their role in the evolution of life. Angew. Chem. Int. Ed. 60, 6242-6269 (2021).

8. Garst, A. D., Edwards, A. L. \& Batey, R. T. Riboswitches: structures and mechanisms. Cold Spring Harb. Perspect. Biol. 3, a003533 (2011).

9. Motorin, Y. \& Helm, M. RNA nucleotide methylation. Wiley Interdiscip. Rev. RNA 2, 611-631 (2011).

10. Zhao, B. S., Roundtree, I. A. \& He, C. Post-transcriptional gene regulation by mRNA modifications. Nat. Rev. Mol. Cell Biol. 18, 31-42 (2017).

11. Wiener, D. \& Schwartz, S. The epitranscriptome beyond $\mathrm{m}^{6} \mathrm{~A}$. Nat. Rev. Genet. 22, 119-131 (2021).

12. Andexer, J. N. \& Rentmeister, A. Challenging nature's preference for methylation. Nat. Chem. 12, 791-792 (2020).

13. Serganov, A. \& Patel, D. J. Molecular recognition and function of riboswitches. Curr. Opin. Struct. Biol. 22, 279-286 (2012).

14. Schwalbe, H., Buck, J., Fürtig, B., Noeske, J. \& Wöhnert, J. Structures of RNA switches: insight into molecular recognition and tertiary structure. Angew. Chem. Int. Ed. 46, 1212-1219 (2007)

15. Ferré-D'Amaré, A. R. The glmS ribozyme: use of a small molecule coenzyme by a gene-regulatory RNA. Q. Rev. Biophys. 43, 423-447 (2010).

16. Scheitl, C. P. M., Ghaem Maghami, M., Lenz, A. K. \& Höbartner, C. Sitespecific RNA methylation by a methyltransferase ribozyme. Nature $\mathbf{5 8 7}$, 663-667 (2020).

17. Bédard, A. V., Hien, E. D. M. \& Lafontaine, D. A. Riboswitch regulation mechanisms: RNA, metabolites and regulatory proteins. Biochim. Biophys Acta Gene Regul. Mech. 1863, 194501 (2020).

18. McCown, P. J., Corbino, K. A., Stav, S., Sherlock, M. E. \& Breaker, R. R. Riboswitch diversity and distribution. RNA 23, 995-1011 (2017).

19. Price, I. R., Grigg, J. C. \& Ke, A. Common themes and differences in SAM recognition among SAM riboswitches. Biochim. Biophys. Acta 1839, 931-938 (2014).

20. Sun, A. et al. SAM-VI riboswitch structure and signature for ligand discrimination. Nat. Commun. 10, 5728 (2019).

21. Gilbert, S. D., Reyes, F. E., Edwards, A. L. \& Batey, R. T. Adaptive ligand binding by the purine riboswitch in the recognition of guanine and adenine analogs. Structure 17, 857-868 (2009).

22. Jenkins, J. L., Krucinska, J., McCarty, R. M., Bandarian, V. \& Wedekind, J. E. Comparison of a preQ $_{1}$ riboswitch aptamer in metabolite-bound and free states with implications for gene regulation. J. Biol. Chem. 286, 24626-24637 (2011).

23. Klein, D. J., Edwards, T. E. \& Ferré-D’Amaré, A. R. Cocrystal structure of a class $I_{\text {preQ }}$ riboswitch reveals a pseudoknot recognizing an essential hypermodified nucleobase. Nat. Struct. Mol. Biol. 16, 343-344 (2009).

24. Schroeder, G. M. et al. Analysis of a preQ ${ }_{1}-\mathrm{I}$ riboswitch in effector-free and bound states reveals a metabolite-programmed nucleobase-stacking spine that controls gene regulation. Nucleic Acids Res. 48, 8146-8164 (2020).

25. Han, X., Jin, M., Breuker, K. \& McLafferty, F. W. Extending top-down mass spectrometry to proteins with masses greater than 200 kilodaltons. Science 314, 109-112 (2006).

26. Liko, I., Allison, T. M., Hopper, J. T. \& Robinson, C. V. Mass spectrometry guided structural biology. Curr. Opin. Struct. Biol. 40, 136-144 (2016).

27. Glasner, H., Riml, C., Micura, R. \& Breuker, K. Label-free, direct localization and relative quantitation of the RNA nucleobase methylations $\mathrm{m}^{6} \mathrm{~A}, \mathrm{~m}^{5} \mathrm{C}$ $\mathrm{m}^{3} \mathrm{U}$, and $\mathrm{m}^{5} \mathrm{U}$ by top-down mass spectrometry. Nucleic Acids Res. 45, 8014-8025 (2017).

28. Frener, M. \& Micura, R. Conformational rearrangements of individual nucleotides during RNA-ligand binding are rate-differentiated. J. Am. Chem. Soc. 138, 3627-3630 (2016).

29. McCown, P. J., Liang, J. J., Weinberg, Z. \& Breaker, R. R. Structural, functional, and taxonomic diversity of three $\mathrm{preQ}_{1}$ riboswitch classes. Chem. Biol. 21, 880-889 (2014).

30. Liberman, J. A., Salim, M., Krucinska, J. \& Wedekind, J. E. Structure of a class II preQ $_{1}$ riboswitch reveals ligand recognition by a new fold. Nat. Chem. Biol. 9, 353-355 (2013).

31. Liberman, J. A. et al. Structural analysis of a class III preQ $\mathrm{p}_{1}$ riboswitch reveals an aptamer distant from a ribosome-binding site regulated by fast dynamics. Proc. Natl Acad. Sci. USA 112, E3485-E3494 (2015).

32. Iwata-Reuyl, D. An embarrassment of riches: the enzymology of RNA modification. Curr. Opin. Chem. Biol. 12, 126-133 (2008).
33. Durand, J. M. B., Dagberg, B., Uhlin, B. E. \& Björk, G. R. Transfer RNA modification, temperature and DNA superhelicity have a common target in the regulatory network of the virulence of Shigella flexneri: the expression of the virF gene. Mol. Microbiol. 35, 924-935 (2000).

34. Rakovich, T. et al. Queuosine deficiency in eukaryotes compromises tyrosine production through increased tetrahydrobiopterin oxidation. J. Biol. Chem. 286, 19354-19363 (2011).

35. Iijima, M. et al. A guanine derivative as a new MEK inhibitor produced by Streptomyces sp. MK63-43F2. J. Antibiotics 71, 135-138 (2018).

36. Shuai, H., Myronovskyi, M., Nadmid, S. \& Luzhetskyy, A. Identification of a biosynthetic gene cluster responsible for the production of a new pyrrolopyrimidine natural product-huimycin. Biomolecules 10, 1074 (2020).

37. Ignatova, V. V. et al. METTL6 is a tRNA $\mathrm{m}^{3} \mathrm{C}$ methyltransferase that regulates pluripotency and tumor cell growth. Sci. Adv. 6, eaaz4551 (2020).

38. Lentini, J. M., Alsaif, H. S., Faqeih, E., Alkuraya, F. S. \& Fu, D. DALRD3 encodes a protein mutated in epileptic encephalopathy that targets arginine tRNAs for 3-methylcytosine modification. Nat. Commun. 11, 2510 (2020).

39. Han, L., Marcus, E., D’Silva, S. \& Phizicky, E. M. S. cerevisiae Trm140 has two recognition modes for 3-methylcytidine modification of the anticodon loop of tRNA substrates. RNA 23, 406-419 (2017).

40. Arimbasseri, A. G. et al. Evolving specificity of tRNA 3-methyl-cytidine-32 $\left(\mathrm{m}^{3} \mathrm{C} 32\right)$ modification: a subset of tRNAsSer requires N6-isopentenylation of A37. RNA 22, 1400-1410 (2016).

41. Rubio, M. A. T. et al. Editing and methylation at a single site by functionally interdependent activities. Nature 542, 494-497 (2017).

42. $\mathrm{Xu}, \mathrm{L}$. et al. Three distinct 3-methylcytidine $\left(\mathrm{m}^{3} \mathrm{C}\right)$ methyltransferases modify tRNA and mRNA in mice and humans. J. Biol. Chem. 292, 14695-14703 (2017).

43. Ma, C. J., Ding, J. H., Ye, T. T., Yuan, B. F. \& Feng, Y. Q. AlkB homologue 1 demethylates N3-methylcytidine in mRNA of Mammals. ACS Chem. Biol. 14 1418-1425 (2019)

44. Marchand, V. et al. AlkAniline-Seq: profiling of $\mathrm{m}^{7} \mathrm{G}$ and $\mathrm{m}^{3} \mathrm{C}$ RNA modifications at single nucleotide resolution. Angew. Chem. Int. Ed. 57, 16785-16790 (2018)

45. Cui, J., Liu, Q., Sendinc, E., Shi, Y. \& Gregory, R. I. Nucleotide resolution profiling of $\mathrm{m}^{3} \mathrm{C}$ RNA modification by HAC-seq. Nucleic Acids Res. 49, e27 (2021).

46. Ishida, S., Terasaka, N., Katoh, T. \& Suga, H. An aminoacylation ribozyme evolved from a natural tRNA-sensing T-box riboswitch. Nat. Chem. Biol. 16, 702-709 (2020).

47. Burke, D. H. \& Gold, L. RNA aptamers to the adenosine moiety of S-adenosyl methionine: structural inferences from variations on a theme and the reproducibility of SELEX. Nucleic Acids Res. 25, 2020-2024 (1997).

48. $\mathrm{Xu}$, J. et al. Selective prebiotic formation of RNA pyrimidine and DNA purine nucleosides. Nature 582, 60-66 (2020).

49. Höfer, K. \& Jäschke, A. Epitranscriptomics: RNA modifications in bacteria and archaea. Microbiol. Spectr. 6, 3 (2018)

50. Waddell, T. G., Eilders, L. L., Patel, B. P. \& Sims, M. Prebiotic methylation and the evolution of methyl transfer reactions in living cells. Orig. Life Evol. Biosph. 30, 539-548 (2000).

51. Traube, F. R. \& Carell, T. The chemistries and consequences of DNA and RNA methylation and demethylation. RNA Biol. 14, 1099-1107 (2017).

52. Schneider, C. et al. Noncanonical RNA nucleosides as molecular fossils of an early Earth-generation by prebiotic methylations and carbamoylations. Angew. Chem. Int. Ed. 57, 5943-5946 (2018).

53. Pitsch, S., Weiss, P. A., Jenny, L., Stutz, A. \& Wu, X. Reliable chemical synthesis of oligoribonucleotides (RNA) with $2^{\prime}-O-[($ triisopropylsilyl)oxy] methyl(2'-O-tom)-protected phosphoramidites. Helv. Chim. Acta 84, 3773-3795 (2001).

54. Höbartner, C. et al. The synthesis of $2^{\prime}-O-[($ triisopropylsilyl)oxy] methyl (TOM) phosphoramidites of methylated ribonucleosides $\left(\mathrm{m}^{1} \mathrm{G}, \mathrm{m}^{2} \mathrm{G}, \mathrm{m}^{2}{ }_{2} \mathrm{G}\right.$, $\mathrm{m}^{1} \mathrm{I}, \mathrm{m}^{3} \mathrm{U}, \mathrm{m}^{4} \mathrm{C}, \mathrm{m}^{6} \mathrm{~A}, \mathrm{~m}^{6}{ }_{2} \mathrm{~A}$ ) for use in automated RNA solid-phase synthesis. Monatshefte Chem. 134, 851-873 (2003).

55. Mao, S. et al. Base pairing and functional insights into N3-methylcytidine $\left(\mathrm{m}^{3} \mathrm{C}\right)$ in RNA. ACS Chem. Biol. 16, 76-85 (2020).

56. Taucher, M. \& Breuker, K. Top-down mass spectrometry for sequencing of larger (up to $61 \mathrm{nt}$ ) RNA by CAD and EDD. J. Am. Soc. Mass Spectrom. 21 918-929 (2010).

\section{Acknowledgements}

We thank Max Himmelstoß (Innsbruck) for mass spectrometric measurements, Christoph Kreutz (Innsbruck) for NMR spectroscopic support, and Daniel Fellner (Innsbruck) for technical support. We thank the following institutions for funding: Austrian Science Fund FWF [P31691, F8011-B to R.M., P30087 to K.B.]; Austrian Research Promotion Agency FFG [West Austrian BioNMR 858017]; Vienna Science and Technology Fund WWTF (LS17-003). 


\section{Author contributions}

L.F., K.B., and R.M. conceived the project and designed experiments. L.F. performed all experiments, except FT-ICR-MS experiments that were performed by S.H. and K.B. S.M. contributed to cofactor and nucleoside phosphoramidite synthesis. L.F. and R.M. analyzed and interpreted the data, with help from S.H., S.M., and K.B. R.M. supervised the project. R.M., K.B., and L.F. wrote the manuscript.

\section{Competing interests}

The authors declare no competing interests.

\section{Additional information}

Supplementary information The online version contains supplementary material available at https://doi.org/10.1038/s41467-021-24193-7.

Correspondence and requests for materials should be addressed to R.M.

Peer review information Nature Communications thanks Juan Alfonzo, Hashim AlHashimi and other, anonymous, reviewers for their contribtuions to the peer review of this work.
Reprints and permission information is available at http://www.nature.com/reprints

Publisher's note Springer Nature remains neutral with regard to jurisdictional claims in published maps and institutional affiliations.

(c) (i) Open Access This article is licensed under a Creative Commons Attribution 4.0 International License, which permits use, sharing, adaptation, distribution and reproduction in any medium or format, as long as you give appropriate credit to the original author(s) and the source, provide a link to the Creative Commons license, and indicate if changes were made. The images or other third party material in this article are included in the article's Creative Commons license, unless indicated otherwise in a credit line to the material. If material is not included in the article's Creative Commons license and your intended use is not permitted by statutory regulation or exceeds the permitted use, you will need to obtain permission directly from the copyright holder. To view a copy of this license, visit http://creativecommons.org/ licenses/by/4.0/.

(C) The Author(s) 2021 